\title{
EFFECTS OF THE SUBSIDIZED STUDENTS' LOAN ON UNIVERSITY ENROLMENT IN GHANA
}

\author{
H. M. Yusif ${ }^{1}$ and I. Yussof ${ }^{2}$ \\ ${ }^{I}$ Department of Economics, KNUST, Kumasi, Ghana \\ ${ }^{2}$ School of Economics, Universiti Kebangsaan Malaysia, Malaysia \\ hadraty@yahoo.co.uk,
}

\begin{abstract}
This paper examines the effect of the subsidized students' loan on university enrolment in Ghana between 1988-2008 using the autoregressive distributed lag (ARDL) framework. It was discovered that the subsidized student loan had positive and significant impact on university enrolment. Per capita gross domestic product (GDP) was also found to have a significant and positive impact on enrolment. No evidence was found that future earnings and foregone earnings influenced enrolment decisions. The findings have very important policy implications for Ghana, for example additional policies aimed at improving the students' loan scheme will have positive impact on both accessibility and efficiency in the university education system.
\end{abstract}

Keywords: subsidized student loan, enrolments, university

\section{INTRODUCTION}

Public universities in Ghana have been funded totally by tax revenue since independence in 1957. This included free tuition, free meals, free accommodation as well as grants for books and living expenses. In the late 1960s the annual costs to the taxpayer for producing a university graduate was estimated at $2,900 \mathrm{New}$ Cedis $(\mathrm{N} \notin)$ per student compared with $\mathrm{N} \notin 377$ for technical/vocational student, $\mathrm{N} \phi 443$ for teacher training, $\mathrm{N} \phi 199$ for secondary school, $\mathrm{N} \notin 20$ for middle school and $\mathrm{N} \notin 20$ for primary school (Addae-Mensah, 2000). On the basis of the rising costs of producing university graduates in the late 1960s, government decided to reform financing of university education. Consequently, in the 1969/70 academic year, gov- ernment decided that only the topmost students in the General Certificate of Education examinations at the Advanced Level (GCE-AL) would be awarded scholarships for university education while the next highly qualified group of GCE-AL candidates would receive bursaries and half-scholarships (McWilliam and Kwamena-Po, 1975). The goal of this university education financing policy was to reduce the burden of university education on national resources and also ensure fair distribution of students among faculties. But, the implication is clear. Some qualified university students, especially low ability students, would have to partly finance their education using private resources.

To provide a cheaper source of funding to stu- 


\section{$51 \quad$ Yusif and Yussof}

dents who did not qualify for scholarship or bursary, government introduced the student loan scheme in 1971. The loan amount was Five Hundred New Cedis (Nф500) per annum and interest free. This loan scheme provoked students' agitation (Addae-Mensah, 2000) and also impacted negatively on intake in the 1971/72 academic year (McWilliam and Kwamena-Po, 1975). Incidentally, there was a coup d'etat in 1972 and just six months after its introduction the military government abolished the scheme.

Yet, the cost-recovery reforms did not stop as the out-of pocket allowance of $\mathrm{N} \notin 100$ given to university students for books was suspended in the 1974/75 academic year (McWilliam and Kwamena-Po, 1975). Subsequently, total public expenditure as a percentage of gross national product (GNP) on education declined from $5.9 \%$ in 1975 to $2.6 \%$ in 1985 (UNESCO Statistical Yearbook, 1999). Also, public expenditure on tertiary education as a percentage of current public expenditure on education declined from $16.8 \%$ in 1975 to $12.5 \%$ in 1984 and declined again to $11.0 \%$ in 1990 (UNESCO Statistical Yearbook, 1999). Indeed, in the whole of Sub-Sahara Africa, Blair (1998) reported that in the 1980s expenditure on higher education fell from $0.7 \%$ to $0.5 \%$ of GNP. Similarly, Banya and Elu (2001) noted that the proportion of education lending for higher education (for Africa) by the World Bank declined from $43 \%$ in 1981 to $35 \%$ in 1985 .

The fact is public universities in Ghana were characterized by lagging revenues and escalating costs. The resultant funding gap created the challenges of maintaining efficiency, improving access and quality of programmes, upgrading of physical plant and facilities, and also retaining faculty (Attuahene, 2006). Indeed, these financing issues in the 1980s were hardly unique to Ghana. The financing of higher education in general has become an issue faced by many governments all over the world (Barr, 2005). The UK, Canada, the USA, China and other countries were facing similar financing problems in their own contexts.

As a panacea to these deepening funding problems in Ghana, further cost-recovery reforms were introduced under the Tertiary Education Reforms programme in the 1980s. These finance reforms required students who benefit from university education to pay part of the costs of their education. In this, free tuition was maintained for all Ghanaian students but they were to pay for room, meals, books, academic facility user fees, residential facility user fees and other charges. Naturally, the costs of university education to students and their parents increased significantly and it is in this regard that the Ghana government introduced again the subsidized loan scheme in 1988. The main objective has been to reduce the cost of university education for Ghanaian students and thus encourage the enrolment of students from disadvantaged homes.

This concept of cost sharing in Ghana was part of the International Monetary Fund (IMF) and The World Bank structural adjustment programmes (SAPs) which Ghana had subscribed to in 1983. It appears the SAPs were neoliberal economic ideologies of market strategy and the government was to withdraw all subsidies from education, health, energy and also remove all controls on interest rate, exchange rate, etc.

Professor D.B. Johnstone, one of the passionate advocates of the concept of cost sharing argues that such trends in the finance reform agenda are grounded in the context of five themes viz 1) expansion and diversification of enrollments; 2) fiscal pressure as measured in low and declining per-student expenditures and as seen in overcrowding, low-paid faculty, lack of academic equipment or libraries, and dilapidated physical plant; 3) the ascendance of market orientations and solutions, and the search for non governmental revenue; 4) the demand for greater accountability on the part of institutions and faculty, to students, employers, and those who pay; and 5) the demand for greater quality 
and efficiency (Johnstone, 1998, 2003, 2004)

Farmer and Barrel (1982) claim that because loans reduce the cost to government on each student, governments were under less financial pressure to restrict entry. Hill and Winston (2006) confirmed Farmer and Barrel (1982) and reported that grants, loans and campus jobs could impact on accessibility thus making it possible for some disadvantaged students to enrol and complete college. However, literature on the impact of the student loan scheme on tertiary enrolments in Ghana is very scarce. To the extent that the loan scheme which had been administered by the Social Security and National Insurance Trust (SSNIT) since 1988 was replaced by the Students Loan Trust Fund (SLTF) without any empirical analysis on how the SSNIT administered loan scheme impacted on tertiary enrolments.

The goal of this paper is to measure the impact of the subsidized student loan scheme on university enrolment in Ghana from 1988 to 2008. For this purpose it is hypothesized that the students loan scheme as operated in Ghana does not have significant impact on tertiary enrolments. It is also hypothesized that graduate earnings and gross domestic product per capita are positively correlated with public university enrolment. In contrast, foregone earning is assumed to have negative effect on enrolment. It should be noted that the SLTF's modus operandi is not expected to be much different from the SSNIT, just that under SLTF science students receive a little more loan amount (420 $\mathrm{GH} \phi$ in 2008/09 academic year) than students offering humanities (380 GH $\varnothing$ in 2008/09 academic year).

\section{Theoretical Framework}

According to the human capital theory postsecondary investment decisions and differences in the enrolment rates of high income students and low income students are explained by two factors. These are the differences in the financing costs (supply schedules) of these groups and the differences in their expected rates of return (demand schedules). The theory thus suggests that equality of opportunity can be achieved when the costs of financing any given amount of investment in human capital is identical for all students. This means they should face identical supply schedules. If that equality is achieved, according to the theory, the remaining differences in investment and enrolment rates are attributable to differences in expected rates of return or to individual consumption valuations of education. Therefore, in the imperfect education market, if optimal investment is to be achieved then government has to provide higher education free or subsidized or give grants to students or offer them loans, especially for low income students (Becker, 1975; Kodde and Ritzen, 1985).

\section{The Student Loan Scheme in Ghana}

The concept of student loan in Ghana may be analyzed in two phases. The first phase was the attempt to reduce the burden of the increasing costs of university education on the scarce national resources in the late 1960s. Under this, the Education Review Committee established in 1966, chaired by Professor A. Kwapong, Vice Chancellor, University of Ghana, recommended government scholarship for only the topmost qualified GCE-AL graduates entering university while half scholarship and bursary were recommended for the middle qualified students. Government supported loan was recommended for students who could not qualify for direct government financial support (Report of the Education Review Committee, 1967). The 1968 Government Budget gave a legal effect to these recommendations and in the $1969 / 1970$ academic year the recommendations were implemented. Consequently, an interest free student loan scheme was introduced in 1971. However, this scheme was suspended in less than one year due to students' agitation and the scheme's negative impact on university enrolment, as stated earlier.

The second phase is linked to the problems of finance that characterized public universities in Ghana in the 1980s due to the severe economic 


\section{Yusif and Yussof}

crisis. This financing conundrum compelled government to introduce cost-sharing in public universities. Consequently, the student loan scheme was re-introduced in 1988 and operated by SSNIT. It was called the Social Security and National Insurance Trust Students Loan Scheme. Between 1988 and 2008 all students received the same loan amount irrespective of programme pursued at the university. For example in the 1988/89 academic year it was $5 \mathrm{GH} \varnothing$ for every student and increased to $350 \mathrm{GH} \phi$ for every student in the 2004/05 academic year. The loan amount was heavily subsidized by government with students paying an interest of 3\% between 1988 and 1994 compared with the 91-day treasury bill rate of interest of between $19 \%$ and $28 \%$ in the same period. From 1994 to 1999 the student interest rate was pegged at $6 \%$ while the treasury bill rate of interest was between $29.5 \%$ and $42 \%$. However, since the year 2000 the 91-day treasury bill rate of interest has fallen significantly to $9.33 \%$ in $2007 / 08$ while the student interest rate has been fixed at $10 \%$. The latter is slightly above the 91-day treasury bill figures of $9.94 \%$ and $9.33 \%$ in $2006 / 07$ and $2007 / 08$ respectively. It is expected that as the gap between the market rate of interest and the student rate of interest declines the market will become one important source of financing tertiary education.

Currently, the loan is disbursed in two instalments through the bank of the student and there is no restriction on the number of public university students who can access it. The major limitations with this loan scheme are as follows. First, considering the cost of living in the country the maximum loan amount of GHC400 (in 2008 ) is not enough to meet the financial needs of students. Second, under the SSNIT student loan scheme, students were to find three contributors to SSNIT as guarantors. This requirement was a source of discrimination, especially against students from the rural areas. It prevented some students from disadvantaged families from accessing the loan since contributors to SSNIT were a small fraction of public sector workers, who constitute a very small proportion of the Ghanaian workforce. Public workers form about $15 \%$ of total number of workers in the country. There are many families without a single contributor to the SSNIT fund. Surprisingly, the newly introduced SLTF has not decisively addressed the issue of guarantors since at least someone with social security number must endorse the loan application.

\section{Trends Analysis}

Table 1 shows the relationship between the yearly loan amounts students received, the students' interest rate and the treasury bill rate of interest between 1988 and 2008. The results indicate that student interest rate was very stable which reflects the fact that it is pegged by the government and does not vary significantly. In contrast, the treasury bill rate is not stable. It increased and reached a high level of $42 \%$ in 1999 and thereafter declined to the level of the student interest rate between 2006 and 2008.

Table 1: Trends in loan amount, student and treasury bill rates of interest (1988-2008)

\begin{tabular}{llll}
\hline YEAR & $\begin{array}{l}\text { Student } \\
\text { Interest } \\
\text { Rate }(\boldsymbol{\%})\end{array}$ & $\begin{array}{l}\text { Treasury } \\
\text { Bill Rate } \\
(\boldsymbol{\%})\end{array}$ & $\begin{array}{l}\text { Loan } \\
\text { Amount } \\
(\mathbf{G H} \boldsymbol{)})\end{array}$ \\
\hline 1988 & 3 & 19.33 & 5 \\
1989 & 3 & 23 & 6 \\
1990 & 3 & 30 & 7 \\
1991 & 3 & 19 & 8 \\
1992 & 3 & 25 & 15 \\
1993 & 3 & 28 & 20 \\
1994 & 6 & 29.5 & 53 \\
1995 & 6 & 40 & 35 \\
1996 & 6 & 42.8 & 60 \\
1997 & 6 & 40 & 70 \\
1998 & 6 & 34.2 & 80 \\
1999 & 6 & 42 & 100 \\
2000 & 10 & 28.9 & 150 \\
2001 & 10 & 28.2 & 150 \\
2002 & 10 & 24.47 & 200 \\
2003 & 10 & 33.1 & 250 \\
2004 & 10 & 16.23 & 350 \\
2005 & 10 & 14.97 & 400 \\
2006 & 10 & 9.94 & 400 \\
2007 & 10 & 9.33 & 400 \\
2008 & 10 & 11.44 & 400 \\
\hline
\end{tabular}

Source: Extracted from SSNIT files 
With regard to the loan amount the trend as in Table1 indicates four phases. From 1988 to 1991 there was a marginal increase from GHC5 to GHC8. Between 1992 and 2000 the rate of increase was relatively higher than from 1988 to 1991 . However, between 2000 and 2005, the loan amount increased significantly from 150 GHC to 400 GHC. This could be due to the rising costs of rent and other student charges and also to compensate students for the significant increase in the student interest rate from $3 \%$ in 1988 to $10 \%$ in 2006 . However, since 2005 the loan amount remained fixed at GHC400.

In addition to the trend analysis, Table 2 shows the mean, median, maximum, minimum and other statistical values for the treasury bill rates, student interest rate and the loan amounts. From 1988 to 2008 the mean values for the treasury bill and student interest rates were $26.16 \%$ and $6.86 \%$ respectively and the significant gap between the two indicates roughly the magnitude of the subsidy.

Table 2: Interest Rates and Loan Statistics

\begin{tabular}{llll}
\hline & $\begin{array}{c}\text { Treasury } \\
\text { Bill Rate } \\
(\boldsymbol{\%})\end{array}$ & $\begin{array}{c}\text { Student } \\
\text { Interest } \\
\text { Rate } \mathbf{( \% )}\end{array}$ & $\begin{array}{c}\text { Loan } \\
\text { Amount } \\
(\mathbf{G H})\end{array}$ \\
\hline Mean & 26.16 & 6.86 & 150.41 \\
Median & 28.00 & 6.00 & 80.00 \\
Maximum & 42.80 & 10.00 & 400.00 \\
Minimum & 9.33 & 3.00 & 5.00 \\
Std Dev. & 10.40 & 3.02 & 152.41 \\
$\begin{array}{l}\text { Skewness } \\
\text { Kurtosis }\end{array}$ & -0.02 & -0.12 & 0.72 \\
$\begin{array}{l}\text { Observa- } \\
\text { tions }\end{array}$ & 21 & 1.39 & 1.94 \\
\hline
\end{tabular}

METHODOLOGY

This section introduces the data sources, discusses the ARDL framework and also specifies the model for estimation.
Data Sources and Variable Description

This paper uses secondary data for the analysis and for enrolment rates the data were obtained from the Planning Unit of the Kwame Nkrumah University of Science and Technology (KNUST), Ghana. Data on student loan were extracted from the files of SSNIT and SLT. Data on minimum wage, proxy for earnings of high school graduates (opportunity cost of university education), were obtained from the records of the Ghana Trades Union Congress (TUC) in Accra. Data on future earnings were extracted from information collected from the Human Resource Departments of the Ghana Health Service and Ghana Water Company Ltd.

The dependent variable is the natural logarithm of annual enrolment rate (lnENROL) while the explanatory variables comprise natural logarithm of future earnings of graduates (lnGE), natural logarithm of per capita gross domestic product (lnGDP/PC), natural logarithm of forgone earnings (lnFE) and the natural logarithm of student loan (lnLOAN). All the data covers the period from 1988 to 2008 .

\section{The ARDL Framework}

In this study the ARDL is employed to measure the effect of the subsidized student loan and other economic variables including per capita GDP, future earnings and forgone earnings on university enrolments in Ghana. The choice of the ARDL is due to two main reasons. First, annual time series data from 1988 to 2008 is used. The dataset thus has 21 observations. Therefore, the two-step residual-based procedure by Engle and Granger (1987) and the system-based reduced rank regression approach by Johansen $(1988,1995)$ methods for testing the null of no cointegration might not give the best results. These alternative methods for testing the null of no cointegration have been found not very reliable for a small number of observations (Narayan and Smyth, 2005) such as we have in this study.

Interestingly, ARDL has been used in many applied studies involving a small number of 


\section{$55 \quad$ Yusif and Yussof}

observations. Narayan and Smyth (2005) investigated the impact of trade liberalization on national income in Fiji using annual time series data from 1962 to 2000. Tang (2002) estimated money demand function in Malaysia using annual data from 1973 to 1998, i.e. 26 observations. Tang (2001) modelled inflation in Malaysia employing annual data from 1973 to 1997 i.e. 25 observations. Tang and Nair (2002) estimated import demand function for Malaysia using annual data from 1970 to 1998 i.e. 29 observations. Pattichis (1999) also estimated disaggregated import demand function for Cyprus with annual time series data from 1975 to 1994 with 20 observations.

Second, we adopted the ARDL framework on the grounds that there is some doubt about the order of integration of the time series variables - future earnings, foregone earnings, per capita GDP and the subsidized student loan. The two main methods of cointegration by Engle and Granger (1987) and Johansen (1988, 1995) require the time series variables to be integrated of order one i.e. the first difference must be stationary which is denoted as I(1). The impression is that the Engle and Granger (1987) and Johansen (1988, 1995) methods of cointegration depend on pre-testing the order of integration of the variables. However, pre-testing introduces some degree of uncertainty into the analysis of the long run relations (Pesaran et al., 1999).

Conversely, the bounds testing approach (ARDL framework) to the analysis of long run relations is applicable whether the variables are $\mathrm{I}(0), \mathrm{I}(1)$ or mutually cointegrated (Pesaran et $a l .$, 1999). Technically, ARDL does not require pre-testing the order of integration of the regressors before testing for long run relations.

In the estimation, we followed Frimpong and Oteng-Abayie (2008), Narayan and Smyth (2005), Pesaran et al. (1999). Thus, first the existence of long run relationship is tested by computing the F statistics. Pesaran et al. (1999) has provided two sets of asymptotic critical values for the classification of the regressors. The upper bound assumes all regressors are I(1) while the lower bound assumes regressors are I (0). If the computed F statistics fall outside the critical bounds then a conclusive decision can be made about the existence or otherwise of cointegration without necessarily knowing the order of integration of the regressors.

Second, the Schwarz Bayesian Criteria is used to select the order of the lags and we then estimated the long run and short run parameters using the models 1 and 2 . The results are reported in Tables 5 to 8 .

\section{Model Specification}

To investigate the effect of the subsidized student loan on university enrolment we estimate Model 1 and Model 2 below using annual time series data. These models represent the long run equilibrium relationships.

Model 1

$L n E N R O L=\alpha_{0}+\alpha_{1} \ln G E+\alpha_{2} \ln G D P /$
$P C+\alpha_{3} \ln L O A N+\alpha_{4} \ln F E+\varepsilon_{t}$

Model 2

LnENROL $=\delta_{0}+\delta_{1} \ln G D P / P C+$ $\delta_{2} \ln L O A N+\delta_{3} \ln F E+\mu_{t}$

In both models, lnENROL is the natural logarithm of enrolment rate, $\operatorname{lnGE}$ is the natural logarithm of graduate earning, $\operatorname{lnGDP} / \mathrm{PC}$ is the natural logarithm of per capita gross domestic product, lnLOAN is the natural logarithm of the subsidized student loan and lnFE is the natural logarithm of foregone earnings. Model 1 contains five variables while Model 2 has four. The coefficient of $\operatorname{lnGE}$ is expected to be positive, LnGDP/PC and lnLOAN are also expected to have positive coefficients. In contrast, $\operatorname{lnFE}$ is opportunity cost of university education and it is expected to have a negative coefficient. The selection of these variables is influenced by the human capital theory (Becker, 1975; Kodde and Ritzen, 1985). 
$\Delta \ln$ ENROL $_{t}=C_{0}+\sum_{i=1}^{n} b_{i} \Delta \ln E_{N R O L_{t-1}}+\sum_{i=0}^{n} d_{i} \Delta \ln G E_{t-1}+\sum_{i=0}^{n} e_{i} \Delta \ln G D P / P C_{t-1}$ $+\sum_{i=0}^{n} f_{i} \Delta \ln L O A N_{t-1}+\sum_{i=0}^{n} g_{i} \Delta \ln F E_{t-1}+\lambda_{1} \ln E N R O L_{t-1}+\lambda_{2} \ln G E_{t-1}+\lambda_{3} \ln G D P / P C_{t-1}$ $+\lambda_{4} \ln L O A N_{t-1}+\lambda_{5} \ln F E_{t-1}+\varepsilon_{t}$

Where $\lambda_{i}$ are the long run multipliers, $\varepsilon_{t}$ is the drift, while $C_{0}$ is error term

\section{RESULTS AND DISCUSSIONS}

As stated earlier, this paper measures the impact of the subsidized students' loan on university enrolment in Ghana. In this section the empirical results are presented and subsequently discussed.

\section{ARDL Cointegration Test Results}

The computed $\mathrm{F}$ statistics that are used to test for the presence of long run relationships are presented in Table 4.

Table 4: Estimated F statistics for cointegration relationship

Critical value bounds of the $F$ statistics

\begin{tabular}{llllllll}
\multicolumn{7}{c}{$90 \%$ level } & \multicolumn{9}{c}{$9 \%$} & level \\
\hline Model & $1(0)$ & $1(1)$ & $1(0)$ & $1(1)$ & $\begin{array}{l}\text { Calcu- } \\
\text { lated }\end{array}$ & $\begin{array}{l}\text { F sta- } \\
\text { tistics }\end{array}$ \\
1 & 2.65 & 3.71 & 3.07 & 4.19 & 4.22, & $(\mathrm{k}=4)$ \\
2 & 2.97 & 4.00 & 3.49 & 4.58 & 6.11, & $(\mathrm{k}=3)$ \\
\hline \multicolumn{7}{l}{ The critical value bounds }
\end{tabular}

The critical value bounds are from Pesaran et al. (1999)

Results in Table 4 thus help us to test the null hypothesis for no cointegration specified as

$H_{0}: \lambda_{1}=\lambda_{2}=\lambda_{3}=\lambda_{4}=\lambda_{5}=0$ against

the alternative hypothesis for cointegration

$H_{1}: \lambda_{1} \neq \lambda_{2} \neq \lambda_{3} \neq \lambda_{4} \neq \lambda_{5} \neq 0$

From the estimates the computed F statistics for models 1 and 2 (4.22 and 6.11) are all higher than the respective upper bounds. Consequently, the null hypothesis of no cointegration may not be accepted. It does appear that long run cointegration relationships exist between the variables. Consequently, we proceed with the estimation of the long run and short run coefficients for the two models.

\section{Long Run Results}

The variable of interest in this study is the subsidized student loan and based on economic theory the paper also controlled for future earnings, per capita GDP and opportunity cost as explanatory variables. Tuition fee is excluded since in Ghana tuition is free for all Ghanaian students in the public universities. Indeed, academic facility user fee (AFUF) which was introduced in 1997/8 academic year was also excluded because of inadequate data.

In Table 5, the long run results of Model 1 are presented and reveal that only the LOAN variable is significant. The LOAN variable has positive effect on enrolment as expected and significant at the 5\% error level. This confirms earlier studies (Finnie, 2002; Moore et al., 1991; St. John, 1990) which reported that enrolments are sensitive to changes in loans. Heller (1997) also predicted that college enrolments were more sensitive to increase in grants than in loans.

Table 5: Long Run Results of Model 1, 1988-2008

\begin{tabular}{lllll}
\hline $\begin{array}{l}\text { Regres- } \\
\text { sors }\end{array}$ & $\begin{array}{l}\text { Coeffi- } \\
\text { cient }\end{array}$ & $\begin{array}{l}\text { Stan- } \\
\text { dard } \\
\text { Error }\end{array}$ & $\begin{array}{l}\text { T- } \\
\text { Ratio }\end{array}$ & $\begin{array}{l}\text { P- } \\
\text { Value }\end{array}$ \\
\hline LnGE & -.11869 & .25066 & -.47351 & .647 \\
LnGDP/ & .83278 & .52362 & 1.5904 & .146 \\
PC & & & & \\
LnLOAN & .24411 & .10324 & 2.3646 & .042 \\
LnFE & .16198 & .24299 & .66660 & .522 \\
Constant & 4.0529 & 2.8144 & 1.4401 & .184 \\
\hline
\end{tabular}




\section{$57 \quad$ Yusif and Yussof}

Indeed, the long run results for Model 1 appear very bad since only the LOAN variable is statistically significant. Therefore, we dropped the GE variable as indicated in Model 2 and run the regression.

The estimates presented in Table 6 show that the student loan variable has a positive effect on enrolment at a $10 \%$ error level. The per capita GDP variable has a positive effect on enrolment and it is significant at the $10 \%$ error level. However, the opportunity cost variable i.e. the earnings of senior high school graduates in the labour market has the negative sign. This negative sign is theoretically plausible but the variable is found to be statistically insignificant in enrolment decisions.

This seems to support the reality in the Ghanaian context and might be explained by the following factors. First, the rate of unemployment among high school graduates is very high and hence their earnings do not seem to have significant impact on enrolment decisions. Second, the earnings of employees with secondary school qualification is very low compared with earnings of employees with tertiary qualifications. Appiah-Kubi (2003) reported that employees who completed tertiary education in Ghana earn in real terms 58\% more than those who completed secondary schooling. Again data collected from the Ghana Health Service indicate that an employee with university degree earned more than three times that of an employee with secondary qualification while in the public universities the gap is a little over two times higher. Therefore the opportunity cost variable might not significantly influence university enrolments.

Table 6: Long Run Results of Model 2, 1988-2008

\begin{tabular}{lllll}
\hline Regressors & $\begin{array}{l}\text { Coeffi- } \\
\text { cient }\end{array}$ & $\begin{array}{l}\text { Stan- } \\
\text { dard } \\
\text { Error }\end{array}$ & $\begin{array}{l}\text { T- } \\
\text { Ratio }\end{array}$ & $\begin{array}{l}\text { P- } \\
\text { Value }\end{array}$ \\
\hline LnGDP/PC & .98365 & .48520 & 2.0273 & .068 \\
LnLOAN & .78419 & .38600 & 2.0316 & .067 \\
LnFE & -.42239 & .36175 & -1.1676 & .268 \\
Constant & 2.2444 & 2.7388 & .81949 & .430 \\
\hline
\end{tabular}

\section{Short Run Results}

Short run results are presented in Tables 7 and 8. Both tables show that the error correction term is negative as expected. This confirms the earlier results that long run equilibrium relationships exist between the variables. The coefficients are -.48985 for the model with future earnings (Model 1) and -.37960 for the model without the future earnings variable (Model 2). They are all significant at the 5\% level. These results suggest that it takes between 4 and 5 months for convergence to long run equilibrium when there is a shock.

The estimated coefficients of the predictors show that previous enrolment figures have positive and significant impact on enrolment. Future earnings and student loan are also shown to have significant but negative impact on enrolment in the short run. However, results in Table 8 indicate that student loan does not have significant impact on enrolment in the short run.

The regression results seem to have very important policy implications for Ghana. In 1997/98 academic facility user fees and residential facility user fees were introduced in public universities. Consequently, the cost of pursuing university education to those who benefit directly has increased and this could have negative impact on access, especially for low-income earners. Such developments might contradict government policy of improving access to tertiary education and also impact negatively on government objective of attaining middle income status by 2015 . In this regard financial aid in the form of loans or grants should be made available to as many tertiary students as possible.

Again, researchers have predicted that quality human capital is very important for sustainable growth and improved economic performance. Thus, if Ghana is to achieve very rapid rate of growth and development then much more financial assistance in the form of scholarships and grants in addition to the loans should be 
Table 7: Short run Results of Model 1, 1988-2008

\begin{tabular}{lllll}
\hline Regressors & Coefficient & Standard Error & T- Ratio & P-Value \\
\hline dLnENROL1 & .82674 & .26066 & 3.1718 & .009 \\
DLnGE & -.31817 & .11887 & -2.6766 & .022 \\
dLnGDP/PC & .40794 & .30864 & 1.3217 & .213 \\
DLnLOAN & .014939 & .029061 & .51407 & .617 \\
dLnLOAN1 & -.10183 & .027390 & -3.7178 & .003 \\
DLnFE & .079344 & .11887 & .66750 & .518 \\
Dc & 1.9853 & 1.3607 & 1.4591 & .173 \\
ecm $(-1)$ & -.48985 & .16523 & -2.9647 & .013 \\
\hline
\end{tabular}

Model Diagnostics

$R$-Squared: .76645, R-Bar-Squared: .53290

F-stat. $F(7,11)$ 4.2194[.017], DW-statistic: 2.6962

Akaike Info. Criterion: 27.8817, Schwarz Bayesian Criterion: 23.1595

Table 8: Short run Results of Model 2, 1988-2008

\begin{tabular}{lllll}
\hline Regressors & Coefficient & Standard Error & T- Ratio & P-Value \\
\hline dLnGDP/PC &.- .43206 & .36245 & -1.1920 & .255 \\
DLnLOAN & -.032091 & .068783 & -.46655 & .649 \\
dLnLOAN1 & -.20242 & .060278 & -3.3581 & .005 \\
DLnFE & -.16034 & .10041 & -1.5969 & .134 \\
Dc & .85199 & 1.1014 & .77352 & .453 \\
ecm $(-1)$ & -.37960 & .14247 & -2.6644 & .019 \\
\hline
\end{tabular}

Model Diagnostics

R-Squared: .73540, R-Bar-Squared: .56701

F-stat. F( 5, 13) 6.1144[.004], DW-statistic: 2.5194

Akaike Info. Criterion: 28.6957, Schwarz Bayesian Criterion: 24.9179

made available to tertiary students in order to improve significantly the very low gross enrolment ratio of $5 \%$ (in 2006) in the country.

Finally, in the $21^{\text {st }}$ century the world has become a knowledge-based society and all coun- tries, both developed and developing are striving to provide quality higher education to as many citizens as possible. Therefore, if Ghana is to be part of an economic revolution in Africa then financial aid should be provided for all qualified students who need it. 


\section{CONCLUSION}

In this paper we examined the effect of the student loan scheme introduced by the Ghana government on public university enrolment between 1988 and 2008. We adopted the ARDL approach to cointegration and estimated the long run and short run coefficients first using natural logarithm of nominal values of five variables namely; enrolment, per capita GDP, subsidized student loan, earning of university graduates and earning of high school graduates. Second, we run the regression without the variable for future university graduate earnings. We discovered three important things in the long run results. First, the subsidized student loan has positive and significant influence on university enrolment in the two regression results. This reflects the fact that financial aid in general has an important influence on university enrolment. We also found that per capita GDP has positive and significant effect on enrolment in the results without future earnings. The implication is that improvement in the incomes of people has direct positive impact on their demand for higher education in Ghana. This appears to suggest that higher education is a normal good in Ghana. We also found that opportunity cost of university education has negative sign as expected but not important in enrolment decisions in Ghana. We conclude that this study has important policy implications for Ghana, especially with regards to accessibility and efficiency in the university education system.

\section{REFERENCES}

Addae-Mensah, I. (2000). Education in Ghana: A Tool for Social Mobility or Social Stratification? Institute For Scientific and Technological Information, Accra

Appiah-Kubi, K. (2003). Education Inequality in Ghana, Centre for Policy Analysis, MMAP Ghana Research Report No.1, Accra
Atuahene, F. (2006). A Policy analysis of the financing of tertiary education institutions in Ghana: An assessment of the objectives and the impact of the Ghana Education Trust Fund. (PhD Dissertation), Faculty of the College of Education of Ohio University

Banya, K. and Elu, J. (2001). The World Bank and financing higher education in Sub Sahara Africa, , Kluver Academic Publishers, Netherlands, Higher Education, 42:1-34.

Barr, N. (2005). Financing higher education, Finance \& Development, June, 34-37 Washington D.C.

Becker, G. S. (1975). Human Capital: A Theoretical and Empirical Analysis with Special Reference to Education, $2^{\text {nd }}$ Edition, National Bureau of Economic Research, New York

Engle, R. F. and Granger, C. W. J. (1987). Cointegration and Error Correction Representation: Estimation and Testing, Econometrica, 55:251-276

Farmer, M. and Barrell, R. (1982). Why student loans are fairer than grants, Public Money, June, 1982, 2 (1):1924

Finnie, R. (2002). Student Loans, Student Financial Aid and Post-secondary Education in Canada, Journal of Higher Education Policy and Management, 24 (2): 155-170

Frimpong, J. M. \& Oteng-Abayie, E. F. (2008). Bounds Testing Approach: An Examination of Foreign Direct Investment, Trade, and Growth Relationships, American Journal of Applied Sciences, 3, (11):20792085 
Effects of the Subsidized Students' Loan...

Heller, D. E. (1997). Student Price Response in Higher Education, The Journal of Higher Education; Nov/Dec. 68 (6): 624-659

Hill, C. B. and Winston, G. C. (2006). Access: Net prices, affordability, and equity at a highly selective college, Economics of Education Review, 25:29-41

Johansen, S. (1988). Statistical analysis of cointegrating vectors, Journal of Economic Dynamics and Control, 12:231-254

Johansen, S. (1995). Likelihood-Based Inference in Cointegrated Vector Auto regressive Models . Oxford University Press, Oxford.

Johnstone, D. B. (1998). The Financing and Management of Higher Education: a status report on worldwide reforms. Washington: World Bank.

Johnstone, D. B. (2003). Cost-sharing and equity in higher education: Implications of income contingent loans. Paper delivered at the Douro III Seminar in Portugal October 2003

Johnstone, D. B. (2004). The Economics and Politics of Cost Sharing in Higher Education: Comparative Perspective, Economics of Education Review, August, 23(4): 403-410

Kodde, D. A and Ritzen, J. M. M. (1985), The demand for education under capital market imperfections, European Economic Review 28:347-362, Elsevier Science Publishers B.V.North-Holland

McWilliam, H. O. A and Kwamena-Po, M. A. (1975). The Development of Education in Ghana: An Outline, Longman Group Ltd, London

Moore, R. L., Studenmund, A. H. and Slobko,
T., (1991). The effect of the financial aid package on the choice of a selective college, Economics of Education Review, 10 (4):311-321

Narayan, P. K and Smyth, R. (2005). Trade Liberalization and Economic Growth in Fiji. An Empirical Assessment Using the ARDL Approach, Journal of the Asia Pacific Economy, 10 (1): 96115

Pattichis, C. A. (1999). Price and income elasticities of disaggregated import demands: Results from UECMs and an application, Applied Economics, 31:1061-1071

Pesaran, M. H., Shin, Y. and Smith, R. J. (1999). Bounds Testing Approaches to the Analysis of Long Run Relationships. Discussion Paper no. 46, Edinburgh School of Economics, University of Edindburgh.

Pesaran, M. H., Shin, Y. and Smith, R. J. (2001). Bounds Testing Approaches to the Analysis of Level Relationships, Journal of Applied Econometrics, 16:289-326

Report of the Education Review Committee, Accra, 1967.

St. John, E. P. (1990). Price response in enrolment decisions: An analysis of the High School and Beyond Sophomore cohort, Research in Higher Education. 31 (2): 161-176

Tang, T. C. (2001). Bank lending and inflation in Malaysia: Assessment from unrestricted error correction models, Asian Economic Journal, 15:275-289

Tang, T. C. (2002). Demand for M3 and expenditure components in Malaysia: Assessment from bounds testing ap- 


\section{Yusif and Yussof}

proach, Applied Economics Letters, 9: 721-725

Tang, T. C. and Nair, M. (2002). A cointegration analysis of Malaysian import demand function: Reassessment from the bounds test, Applied Economics Letters, 9: 293-296

UNESCO Statistical Yearbook (1999). Paris, France 